\title{
Grazing impact of microzooplankton on different size classes of algae in the North Sea in early spring and mid-summer
}

\author{
B. R. Kuipers*, H. J. Witte \\ Netherlands Institute for Sea Research, PO Box 59, 1790 AB Den Burg, Texel, The Netherlands
}

\begin{abstract}
The impact of microzooplankton community grazing on different size classes of algae was investigated at 11 stations between Dogger Bank and the Shetlands in early spring (March-April) and in summer (July-August). This work is part of a larger study designed to test the hypothesis that sizedifferential grazing of phytoplankton populations plays a crucial role in regulating food web structure. Dilution experiments, in which loss rates of the algae due to microzooplankton grazing can be estimated from the relation between growth rate of the prey and dilution, failed in many cases due to high variance. The present paper analyses the problem and puts forward a solution which involved pooling data from comparable stations into 1 average grazing estimate per algal size class. In early spring, estimates of grazing from measurements of chlorophyll a (chl a) were obtained only for algae $>5 \mu \mathrm{m}$, and average grazing rate was $0.23 \mathrm{~d}^{-1}$ at the deeper stations. At the shallower more southern stations where a phytoplankton bloom was in progress the average grazing rate on algae $>5 \mu \mathrm{m}$ was $0.5 \mathrm{~d}^{-1}$ Flow cytometry was more successful in the $<5 \mu \mathrm{m}$ algal fraction, yielding grazing rates of $0.25 \mathrm{~d}^{-1}$ for the southern and $0.31 \mathrm{~d}^{-1}$ for the northern stations. In summer, microzooplankton grazing incubations yielded significant results only when flow cytometry was used, and only when results were pooled for different areas. Grazing rates ranged from $0.07 \mathrm{~d}^{-1}$ in the $1-2 \mu \mathrm{m}$ algal size class to $0.74 \mathrm{~d}^{-1}$ for algae of $3-4 \mu \mathrm{m}$ and were $0.25 \mathrm{~d}^{-1}$ for the $<5 \mu \mathrm{m}$ cluster as a whole.
\end{abstract}

KEY WORDS: Microzooplankton · Grazing · Dilution - Chlorophyll · Flow cytometry $\cdot$ North Sea

\section{INTRODUCTION}

Fixation and enumeration of protozooplankton and the zooplankton size class between 50 and $200 \mu \mathrm{m}$ are relatively easy, but measuring their grazing impact is still very problematic. Consumption rates of specific Protozoa feeding on known food items have been estimated in a number of ways, including microscopic determination of the food vacuole content and evacuation time for ciliates and dinoflagellates (Kuosa 1990, Bockstahler \& Coats 1993), the use of fluorescently labeled bacterioplankton (FLB) for ciliates feeding on bacteria (Sherr et al. 1987, 1989, Gonzalez et al. 1990, Epstein \& Shiharis 1992), the use of a selective metabolic inhibitor (Xiuren \& Vaulot 1992), and measurements of fluorescence in protozoa after being fed on

•E-mail: bouwe@nioz.nl algae or fluorescent beads (Gerritsen et al. 1987, Capriulo \& Degnan 1991, Bird \& Kalff 1993), and in various types of grazing experiments based on size fractionation of natural communities (Rassoulzadegan \& Sheldon 1986, Kuuppo-Leinikki 1990, Moisan et al. 1991) or the use of cultured predators and prey species (Ohman \& Snyder 1991). Landry (1994) discussed the specific weaknesses and strengths of various approaches and suggested an appropriate combination of different methods. Despite its shortcomings (Evans \& Paranjape 1992, Landry et al. 1995), estimation of in situ microzooplankton grazing rates based on the dilution principle of Landry \& Hassett (1982) best represents the actual community grazing rates, since the method leaves grazer and food species composition unchanged, and handling is minimal. Therefore, many protozoan grazing studies use the dilution method. During the last decade, studies based on this method 
have contributed to the development of the concept of a planktonic microbial food web in which grazing by heterotrophs of $\leq 200 \mu \mathrm{m}$ has shown that they can account for 50 to $100 \%$ of the daily primary production, with the pico-and nano-sized algae being subjected to especially intensive grazing (Verity 1985, 1986, Burkill et al. 1987, Gifford 1988, Paranjape 1990, Strom \& Welschmeyer 1991, Kamiyama 1992, McManus \& Ederington-Cantrell 1992, Buskey 1993, Verity et al. 1993, Neuer \& Cowles 1994).

In oligotrophic oceans where small phytoplankton dominate, unicellular grazers appear to be of particular importance. Primary producers in such systems typically belong to the picoplankton and nanophytoplankton, which have high affinities for nutrients and light. high maximum growth rates, and extremely low sedimentation rates. During the last decade, however, evidence has been growing that, in nutrient-rich waters where net-plankton (e.g. diatoms, dinoflagellates, colony-forming algae, etc.) generally dominate, microzooplankton are as active as they are in oligotrophic

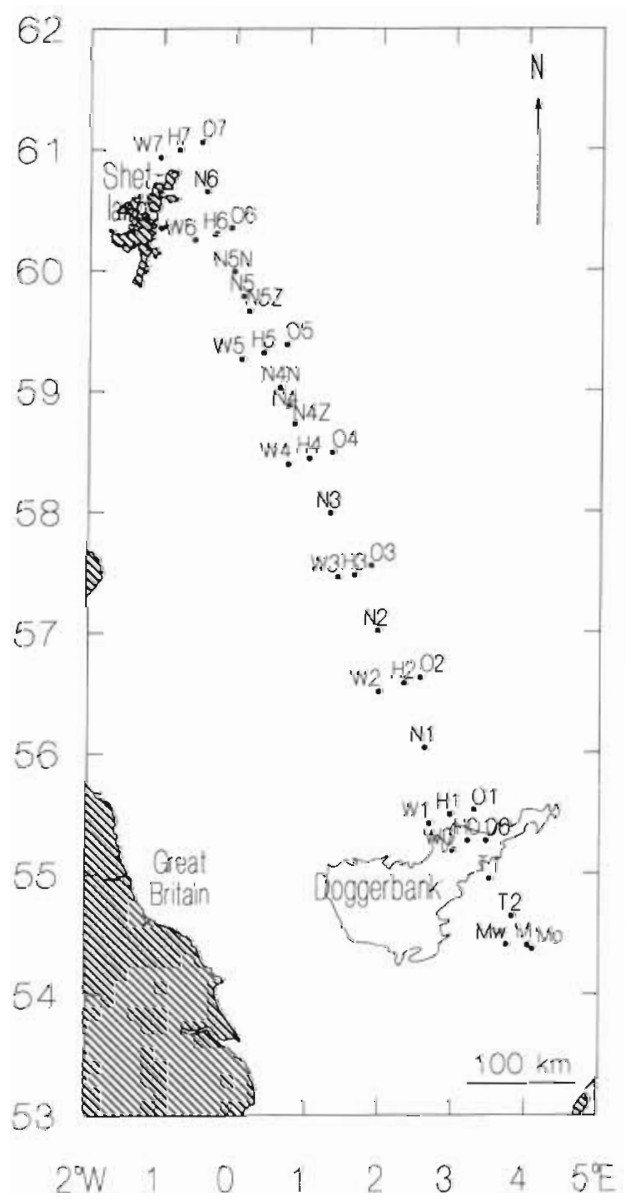

Fig. 1 Sampling stations of the cruises in spring and midsummer 1994 systems, with grazing rates balancing the growth rates of pico- and nanophytoplankton (Verity 1986, Sherr et al. 1989, Paranjape 1990, Frost 1991, Landry et al. 1992, McManus \& Ederington-Cantrell 1992, Riegman et al. 1993). High growth and grazing rates of microzooplankton (Banse 1982) suggest the potential for tight control of their prey populations. Since large phytoplankton lie outside the prey spectrum of microzooplankton (Strom \& Welschmeyer 1991), blooms of larger algae, following nutrient input, seem to be a logical consequence of size-differential grazing by microzooplankton (Kumar et al. 1991, Riegman et al. 1993, Riegman \& Kuipers 1994). In a model exercise by Riegman \& Kuipers (1994), grazing of small phytoplankton by microzooplankton led to channeling of nutrients towards larger phytoplankton and hence, indirectly, into sedimentation because larger phytoplankton sink more rapidly, It is interesting to note that this sedimentation ensures the ultimate return to the oligotrophic clear water conditions and the dominance of the pico- and nanoplanktonic food web once the new nutrients have left the euphotic zone in the sinking material. This manuscript describes a study of microzooplankton grazing which was part of a larger project designed to see if the model described holds true under natural conditions in the northern North Sea.

\section{METHODS}

The northern North Sea transect conducted in spring and mid-summer 1994 (Fig. 1) consisted of a series of major stations, from $\mathrm{H} 1$ on the northern slope of Dogger Bank $\left(55^{\circ} 30^{\prime} \mathrm{N}\right)$ to $\mathrm{H} 7$ northeast of the Shetlands $\left(61^{\circ} 00^{\prime} \mathrm{N}\right)$, with intermediate stations $\mathrm{N} 1$ to $\mathrm{N} 6$ halfway between each pair of the main stations and with other stations $32 \mathrm{~km}$ west (W1-W7) and east (O1-O7) of the $\mathrm{H} 1-\mathrm{H} 7$ line. The whole grid included 27 sampling sites. On some occasions extra stations were occupied (e.g. N5N, N5Z, W0, O0; see Fig, 1).

During the spring cruise the thermocline had not yet developed in the northern North Sea, whereas the phytoplankton spring bloom and the depletion of nutrients were already progressing in the southern North Sea. We had anticipated that light limitation would gradually disappear at the southern stations of our transect, offering the opportunity to study the role of microzooplankton grazing under such transient conditions. The summer cruise was made when nutrient depletion was maximal in the mixed layer of the stratified northern North Sea. In summer a local increase of nutrient levels was expected at the stations in the vicinity of the Shetlands, due to the inflow of nutrientrich Atlantic water from the turbulent Faroe-Shetland 
Channel region. The effect of this nutrient input on the role of microzooplankton grazing in determining food web structure was an important topic for the summer cruise. Microzooplankton were enumerated in $100 \mathrm{ml}$ seawater samples taken at all stations from Niskin bottles filled at 10,20 and $40 \mathrm{~m}$ depth during casts with a CTD Rosette frame. The samples were poured carefully into $100 \mathrm{ml}$ polyethylene jars containing $1.5 \mathrm{ml}$ acid Lugol's solution (final concentration $1.5 \%$ ) and stored in the dark at $4^{\circ} \mathrm{C}$. In the laboratory, the samples were allowed to settle for $78 \mathrm{~h}$ in $100 \mathrm{ml}$ sedimentation tubes for inverted microscopy. The density of microzooplankton was determined for 4 dominating categories (tintinnid ciliates, Strombidium-like ciliates larger than $15 \mu \mathrm{m}$, Strombidium-like ciliates smaller than $15 \mu \mathrm{m}$ and holotrich ciliates). Other microzooplankton, including copepod nauplii and heterotrophic dinoflagellates, were rare in the $100 \mathrm{ml}$ samples and are therefore not considered in the results. Estimates of the volume of the different types were made by measuring dimensions of the best approximate geometrical form. The volume was converted to carbon biomass expressed as $\mu \mathrm{g} \mathrm{C} \mathrm{l}^{-1}$ according to Putt \& Stoecker (1989).

Incubations to estimate grazing were prepared according to the dilution method of Landry \& Hassett (1982) at the main stations $(\mathrm{HO}-\mathrm{H} 7)$ and the stations $\mathrm{M}$, $\mathrm{MB}$ and $\mathrm{MC}$, all 3 at the mooring site $10 \mathrm{~km}$ west of $\mathrm{Mo}$ (see Fig. 1). Two 20 l jars were filled from five $12 \mathrm{l}$ Niskin bottles taken at $10 \mathrm{~m}$ depth and placed on a plankton wheel in a thermostated room at light and temperature conditions simulating $10 \mathrm{~m}$ depth. Immediately thereafter, 10 I was filtered through a Gelman Sciences Micro Culture Capsule $(0.2 \mu \mathrm{m})$ to produce particle-free water for the dilution series, which was checked (by flow cytometry) for particles before use. The incubation series consisted of $100,70,40,20$ and $10 \%$ natural water mixtures prepared in $300 \mathrm{ml}$ polycarbonate bottles in duplicate $10 \%$ always in triplicate) for flow cytometry, and in 1.51 polycarbonate bottles in duplicate for chlorophyll a (chl a) measurement and flow cytometry at $t_{0}$ and $t_{24}$. All bottles were attached for $24 \mathrm{~h}$ to a slowly rotating plankton wheel in the temperature-controlled room, with illumination by daylight TL tubes (Sylvania) corresponding in level and day-night cycle to conditions measured at $10 \mathrm{~m}$ depth. Chl a concentrations were determined on board after fractionation of the samples into size ranges $>5 \mu \mathrm{m}$ and $0.7-5 \mu \mathrm{m}$ by filtration of $1 \mathrm{l}$ through Nuclepore $5 \mu \mathrm{m}$ and Whatman GF/F filters in succession and $24 \mathrm{~h}$ extraction of the filters in $90 \%$ acetone. Chl a measurements were made using a Turner $10 \mathrm{AU}$ fluorometer according to the procedure described in Strickland \& Parsons (1972). Measurements at $t_{24}$ were made on 1 sample per bottle while at $t_{0}$ they were made in triplicate prior to dilution, whereas the $t_{0} \mathrm{chl}$ a concentrations in the diluted bottles were calculated. Additionally, flow cytometry with a Coulter Counter type XL flow cytometer was used to determine the concentration of autotrophs in the range $0-25 \mu \mathrm{m}$. One $\mathrm{ml}$ samples were taken from each incubation bottle at the beginning and end of the incubations and replaced by particle-free water to exclude air bubbles after the sampling at $t_{0}$. Apparent daily growth rate, $k_{i}(=24 / t$. $\ln \left(n_{24} / n_{0}\right)$, where $t=$ duration of experiment, $n=$ cell number, total volume of phytoplankton cells of a given size, or concentration of $\mathrm{chl}$ a), was calculated for each bottle. Linear regressions of $k_{l}$ on dilution provided estimates of apparent growth rate $(k)$ in undiluted seawater and of ungrazed algal growth rate $(\mu)$ by extrapolation to $0 \%$ natural water (no grazing). The difference between $\mu$ and $k$, the estimate of in situ grazing rate $(g)$ for each phytoplankton fraction, was calculated using the expression $\mu-k=-1 \times$ slope.

\section{RESULTS}

\section{Occurrence of microzooplankton}

Microzooplankton biomass distributions in the upper $40 \mathrm{~m}$ along the transect in early spring and summer are given in Fig. 2. Total abundances were less than 1 ind. $\mathrm{ml}^{-1}$, so that there was less than $0.5 \mu \mathrm{g} \mathrm{Cl}^{-1}$ of microzooplankton present at the deeper stations $\mathrm{H} 3-\mathrm{H} 7$ at the end of winter. In the Dogger Bank area the somewhat higher total biomass was due to an increase in Strombidium-like ciliates $>15 \mu \mathrm{m}$, which numbered 2 to 3 ind $\mathrm{ml}^{-1}$. Between March and August considerable changes had taken place in the small categories: in August there were 20 to 50 times more small Strombidium-like ciliates, 10 times more tintinnids at the southern stations and 4 times more holotrich ciliates. Moreover, the Strombidium-like ciliates $>15 \mu \mathrm{m}$ had decreased at the Dogger Bank stations and increased strongly near the Shetlands, especially in the 20 to 40 $m$ depth range where they occurred in numbers of 10 to 20 ind. $\mathrm{ml}^{-1}$ and contributed up to $20 \mu \mathrm{g} \mathrm{Cl}^{-1}$ of the total microzooplankton biomass of $24 \mu \mathrm{g} \mathrm{C}^{-1}$ at stations where early spring values were ca $1 \mu \mathrm{g} \mathrm{Cl}^{-1}$. The biomasses of the 4 microzooplankton categories at $10 \mathrm{~m}$, the depth at which the grazing measurements were made, are shown in Fig. 3.

\section{Grazing rate estimates based on chl a}

Dilution experiments were performed at Stns M-H7 for the phytoplankton fractions $>5$ and $<5 \mu \mathrm{m}$ 


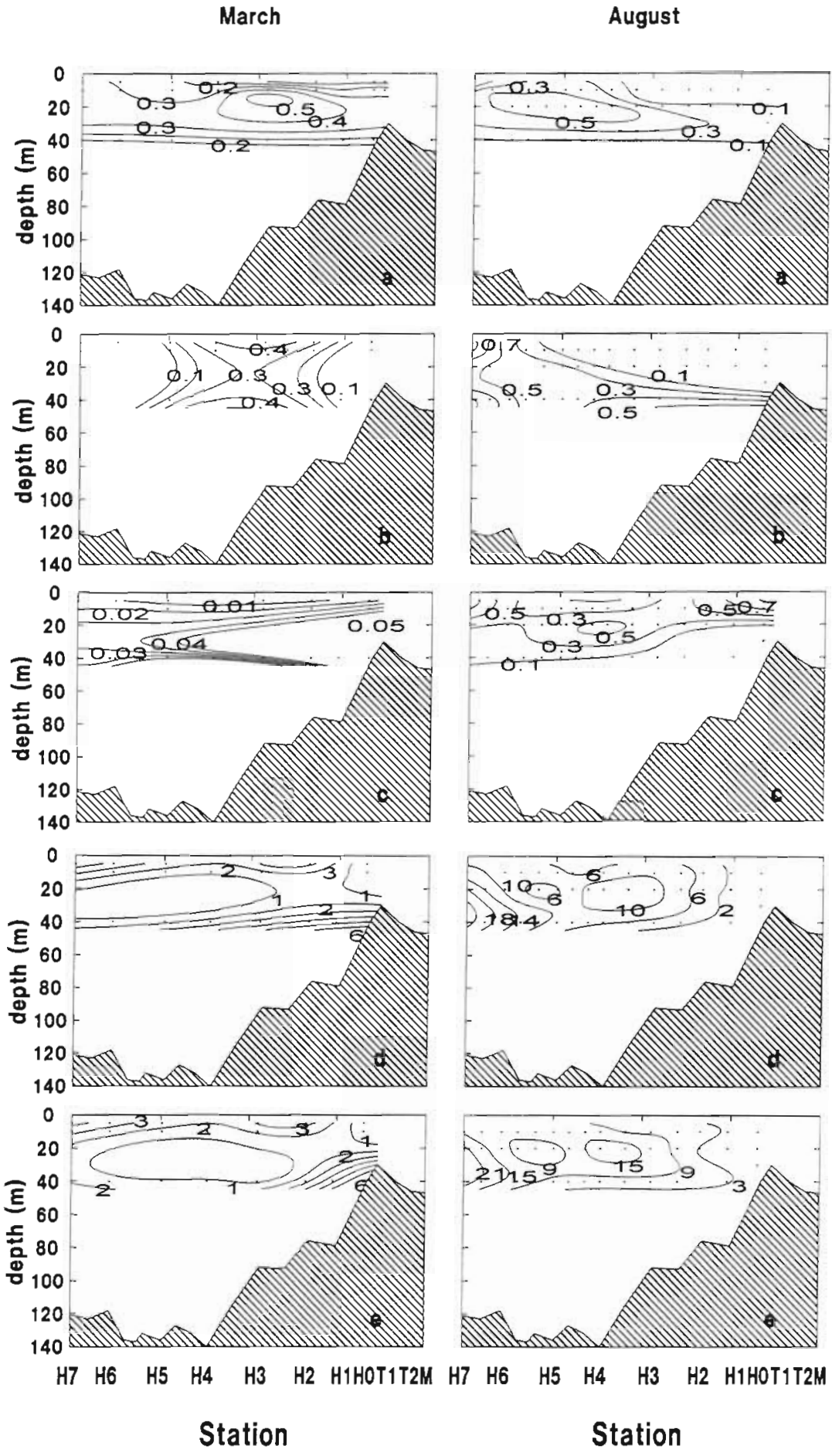

Fig. 2. Distribution of microzooplankton biomass ( $\mu \mathrm{g} \mathrm{Cl}^{-1}$ ) in the upper $40 \mathrm{~m}$ along the transect in spring and mid-summer. Categories: (a) holotrich ciliates, (b) tintinnid ciliates, (c) Strombidium-like ciliates $<15 \mu \mathrm{m}$, (d) Strombidium-like ciliates $>15 \mu \mathrm{m}$ and (e) total microzooplankton

(Table 1). In only 12 out of 46 experiments was there a significant correlation between apparent growth rate and dilution ( $\mathrm{p}<0.05)$ although all dilutions were performed in duplicate at least. The coefficient of variation of the chl a concentration in these duplicates at $t_{24}$ is shown in Fig. 4. The difference between duplicates was moderate for concentrations higher than $0.2 \mu \mathrm{g} \mathrm{L}^{-1}$, but the variance increased rapidly below this value. Since the natural chl a concentrations along the transect were generally lower than $0.5 \mu g \mathrm{I}^{-1}$ (Fig. 5), most 10 and $20 \%$ dilution bottles, containing less than $0.1 \mu \mathrm{g} \quad \mathrm{l}^{-1}$, showed this high variance between duplicates. In order to overcome this problem, the results of dilution experiments at several stations were pooled together into 1 Landry \& Hassett plot for a wider sea area selected on the basis of the chl a concentrations at $10 \mathrm{~m}$ depth (Fig. 6). In March the transect was divided into a southern area, $\mathrm{M}-\mathrm{H} 2$ (the area where a bloom was occurring), and a northern area, $\mathrm{H} 3-\mathrm{H} 7$ (where light-limited winter conditions prevailed). In August the transect was divided into area $\mathrm{M}-\mathrm{H} 5$ (oligotrophic euphotic zone in summer) and area $\mathrm{H} 6-\mathrm{H} 7$ (the Shetland region with increased chl a concentrations). In order that this pooling of data could be done, differences between the horizontal levels of the individual regressions (due to differences in algal growth rate per sampling site) were removed. This was done for each dilution experiment by subtracting the $k_{50 \%}$ (derived from the linear regression) from all the experiments' measured $k$-values (and thus standardizing the $k_{50}$ in each series to 0 ). Although the number of replicates was increased by pooling the data, the Landry \& Hassett plots (Fig. 6) did not show a significant correlation between apparent growth rate and dilution for all areas. The regression parameters and grazing rates given in Table 2 show that only for the algae $>5 \mu \mathrm{m}$ in both areas in March-April and for the $<5 \mu \mathrm{m}$ fraction in summer near the Shetlands did the chl a method yield significant estimates of grazing rate $(p \leq 0.01)$. 

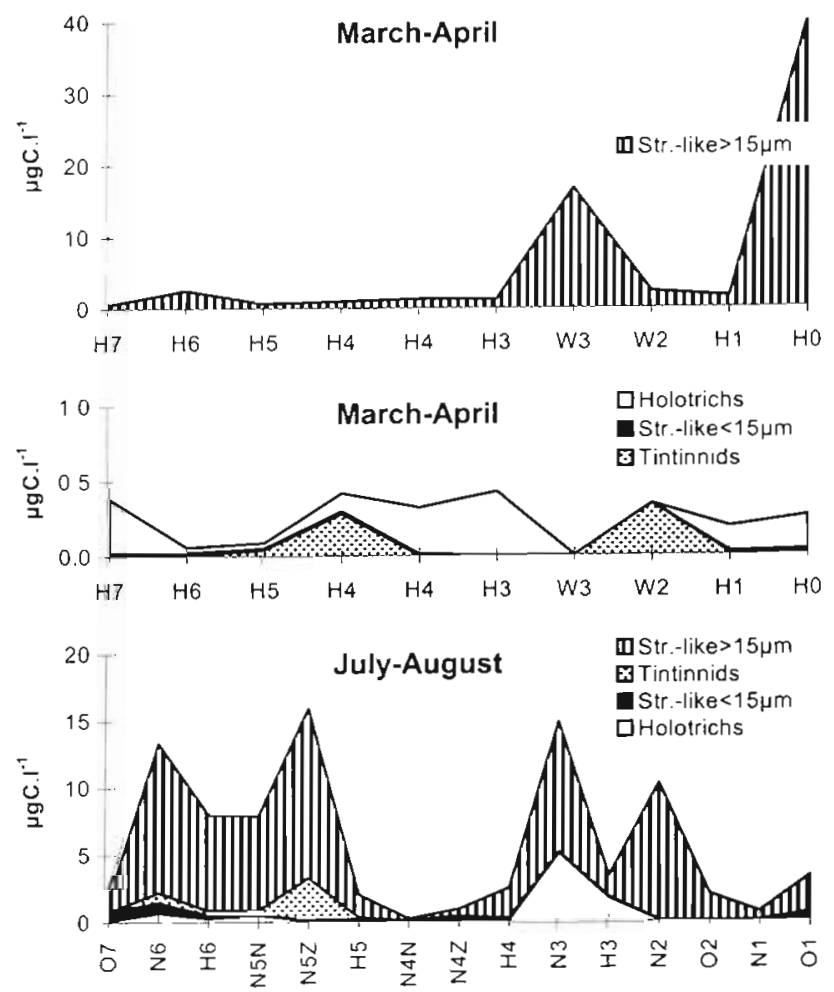

Fig. 3. Biomass of microzooplankton in spring and mid-summer at the depth $(10 \mathrm{~m})$ at which grazing experiments were done

\section{Grazing rate estimates based on flow cytometry}

The assessment of microzooplankton grazing by flow cytometry was concentrated on recognizable clusters of fluorescent particles of which the density and cell size were determined for each dilution bottle at $t_{0}$ and $t_{24}$. Using this approach we were able to examine grazing on 2 dominant clusters of phytoplankton during the early spring cruise: one between 2 and $3 \mu \mathrm{m}$ and one slightly larger than $5 \mu \mathrm{m}$. In summer there were more clusters, ranging in size from $<1$ to $>5 \mu \mathrm{m}$, representing the prochlorophytes and picoeukaryotes, cyanobacteria, various autotrophic nanoflagellates and small algae just larger than $5 \mu \mathrm{m}$. Net-phytoplankton (e.g. diatoms and dinoflagellates) were present in much lower numbers and appeared in the flow cytometer diagrams as single scattered dots because only 0.5 to $1.0 \mathrm{ml}$ volumes were scanned during the 15 min flow cytometer time per sample. The results of the grazing incubations of the main stations are listed in Table 3a for the 2 size categories present in early spring and in Table $3 \mathrm{~b}$ for the 6 size categories distinguished in summer. Although the correlations between $k_{i}$ and dilution determined by flow cytometry were considerably better than in those for the chl a data, many plots still showed too much scatter for clear determinations of grazing. The coefficient of variation of the cell densities in the duplicate bottles at $t_{24}$ plotted against their average (Fig. 7) revealed that when cell counts were

Table 1. Regression parameters for chl a grazing experiments carried out by the dilution method for small and large phytoplankton (separated by $5 \mu \mathrm{m}$ pore size) in spring and mid-summer. Grazing rate, $g\left(\mathrm{~d}^{-1}\right)$, equals $-1 \times$ slope

\begin{tabular}{|c|c|c|c|c|c|c|c|c|c|c|c|c|}
\hline \multicolumn{13}{|l|}{ March-April } \\
\hline Stn: & $: \mathrm{MB}$ & $M$ & $\mathrm{MC}$ & $\mathrm{Ho}$ & $\mathrm{H} 1$ & $\mathrm{H} 2$ & $\mathrm{H} 3$ & $\mathrm{H} 4$ & $\mathrm{H} 4$ & H5 & H6 & $\mathrm{H7}$ \\
\hline Depth (m): & 35 & 40 & 10 & 10 & 10 & 10 & 10 & 6 & 21 & 15 & 13 & 7 \\
\hline Intercept for $<5 \mu \mathrm{m}$ & 0.581 & -1.47 & -0.322 & 0.164 & -0.249 & -0.451 & -0.684 & 0.034 & -0.447 & 0.048 & -0.257 & 0.518 \\
\hline Slope for $<5 \mu \mathrm{m}$ & -0.894 & -0.5 & 0.048 & -0.366 & 1.337 & 0.7 & 1.283 & 0.21 & 0.295 & 0.322 & 0.88 & -0.331 \\
\hline$r^{2}$ & 0.493 & 0.16 & 0.001 & 0.345 & 0.309 & 0.58 & 0.262 & 0.364 & 0.597 & 0.269 & 0.313 & 0.107 \\
\hline $\mathrm{n}$ & 8 & 7 & 8 & 8 & 7 & 8 & 7 & 8 & 8 & 8 & 8 & 8 \\
\hline Intercept for $>5 \mu \mathrm{m}$ & 0.297 & -0.514 & 0.847 & 0.089 & 0.263 & 0.915 & 0.326 & 0.192 & 0.828 & 0.263 & 0.351 & 0.173 \\
\hline Slope for $>5 \mu \mathrm{m}$ & -0.089 & 0.654 & -0.78 & -0.113 & -0.141 & -0.887 & -0.14 & -0.009 & -0.923 & 0.03 & -0.212 & 0.015 \\
\hline$r^{2}$ & 0.012 & 0.27 & 0.447 & 0.048 & 0.084 & 0.889 & 0.179 & 0.003 & 0.689 & 0.036 & 0.46 & 0.001 \\
\hline$n$ & 8 & 7 & 8 & 8 & 7 & 8 & 7 & 8 & 8 & 8 & 8 & 8 \\
\hline \multicolumn{13}{|l|}{ July-August } \\
\hline Stn: & $M$ & $\mathrm{M}$ & & $\mathrm{H} 1$ & H1 & $\mathrm{H} 2$ & H3 & $\mathrm{H} 4$ & $\mathrm{H} 5$ & H5 & H6 & $\mathrm{H} 7$ \\
\hline Depth $(\mathrm{m})$ : & 12 & 25 & & 12 & 10 & 10 & 10 & 10 & 10 & 35 & 10 & 10 \\
\hline Intercept for $<5 \mu \mathrm{m}$ & 0.934 & 0.513 & & 0.354 & 1.096 & 0.84 & 0.422 & 0.357 & 0.824 & -0.147 & 0.619 & 0.257 \\
\hline Slope for $<5 \mu \mathrm{m}$ & 0.411 & 0.229 & & -0.101 & 0.475 & -0.208 & 0.006 & -0.037 & 0.37 & -0.426 & 0.556 & 0.182 \\
\hline $\mathrm{r}^{2}$ & 0.614 & 0.566 & & 0.122 & 0.776 & 0.375 & 0.001 & 0.026 & 0.347 & 0.369 & 0.836 & 0.173 \\
\hline $\mathrm{n}$ & 7 & 9 & & 9 & 9 & 8 & 9 & 8 & 8 & 4 & 9 & 9 \\
\hline Intercept for $>5 \mu \mathrm{m}$ & 0.917 & 0.35 & & 0.516 & 0.945 & 0.543 & 0.063 & 0.103 & 0.232 & 1.242 & 0.474 & -0.217 \\
\hline Slope for $>5 \mu \mathrm{m}$ & -0.561 & -0.023 & & -0.092 & -0.17 & 0.126 & 0.081 & -0.415 & 0.129 & -0.658 & -0.309 & 0.432 \\
\hline$r^{2}$ & 0.614 & 0.566 & & 0.122 & 0.776 & 0.375 & 0.001 & 0.026 & 0.347 & 0.369 & 0.836 & 0.173 \\
\hline$n$ & 7 & 9 & & 9 & 9 & 8 & 9 & 8 & 8 & 4 & 9 & 9 \\
\hline
\end{tabular}



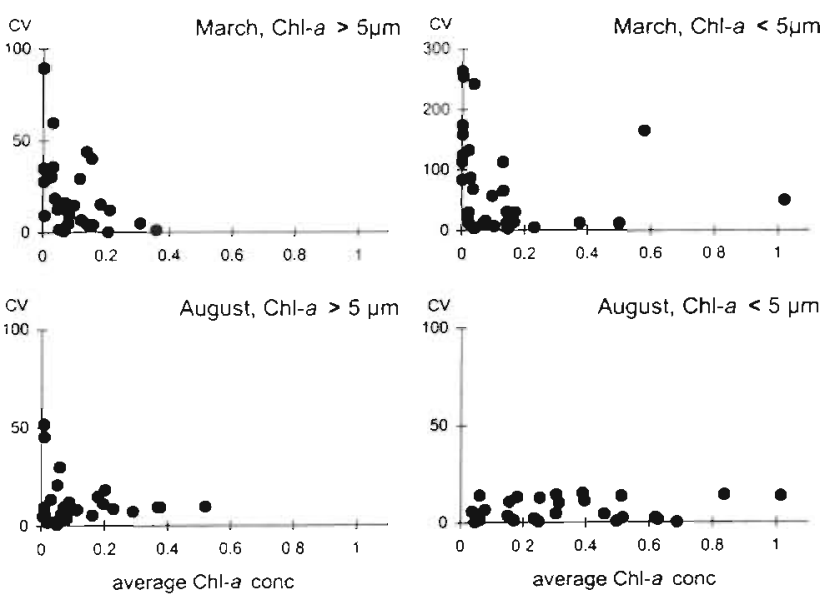

Fig. 4. Coefficient of variation, $\mathrm{CV}$ ( $=\mathrm{SD} /$ average $\times 100 \%$ ), of chl a concentration $\left(\mu \mathrm{g} \mathrm{l}^{-1}\right)$ in duplicate incubation bottles at $t_{24}$ versus average chl a concentration at $t_{24}$ for the $<5$ and $>5 \mu \mathrm{m}$ phytoplankton fractions in spring and mid-summer

below 300 to 500 , the measuring error increased rapidly. This means that often in March the 20 and $10 \%$ dilutions did not contain enough material for an accurate estimation of the differences between the numbers at $t_{0}$ and $t_{24}$. In August grazing could be assessed more accurately due to densities of the nanophytoplankton being 10 times higher. In order to lower the variance, the flow cytometer data were grouped in the same way as the chl a data: for March the transect was divided into the areas $\mathrm{M}-\mathrm{H} 2$ and $\mathrm{H} 3-\mathrm{H} 7$, and for August into areas $\mathrm{M}-\mathrm{H} 5$ and $\mathrm{H} 6-\mathrm{H} 7$ (for stations and chl a see Figs. 1 \& 5). After subtracting $k_{50 \%}$ from all $k_{1}$ per dilution series, Landry \& Hassett plots were made for March (Fig. 8) and August (Fig. 9). Microzooplankton grazing rates $(g)$ per size class per area for the 2 seasons (Table 4) are based on cell numbers per cluster at $t_{0}$ and $t_{24}$, except for the overall cat- egory $<5 \mu \mathrm{m}$ in August, where grazing was based on biomass instead of numbers in the clusters, because the latter were strongly dominated by the size category 1-2 $\mu \mathrm{m}$ whereas the algae of 4-5 $\mu \mathrm{m}$ dominated the biomass (Fig. 10).

\section{Food preference}

During the summer cruise the nanophytoplankton in the oligotrophic surface layer (August, $\mathrm{M}-\mathrm{H} 5$ ) and the Shetland region ( $\mathrm{H} 6-\mathrm{H} 7)$ consisted of 6 size categories determined by flow cytometry. The average densities and relative biovolume (= number $x$ forward scatter position, FS) of these are given in Fig. 10, together with the overall microzooplankton grazing rates for each prey size (from Table 4). The estimated grazing rates did not reflect the prey density, but followed more or less the available biomass in the different size classes. However, grazing on the 3-4 $\mu \mathrm{m}$ algae in the oligotrophic area (M-H5) was exceptionally strong, which may point to a preference of the microzooplankton for nanophytoplankton of this size.

\section{DISCUSSION}

\section{Grazing in the light-limited winter situation}

In the northern area $(\mathrm{H} 3-\mathrm{H} 7)$, where winter conditions prevailed, chl a concentrations were low and evenly distributed with roughly equal proportions of $<5 \mu \mathrm{m}$ and $>5 \mu \mathrm{m}$ algae. Algal growth in the area at this time (March-April) was assumed to have been strongly limited by light availability, and loss rates were probably due mainly to grazing and to a lesser extent to sedimentation because vertical mixing was extensive. Algal growth rates in the $\mathrm{H} 3-\mathrm{H} 7$ area in
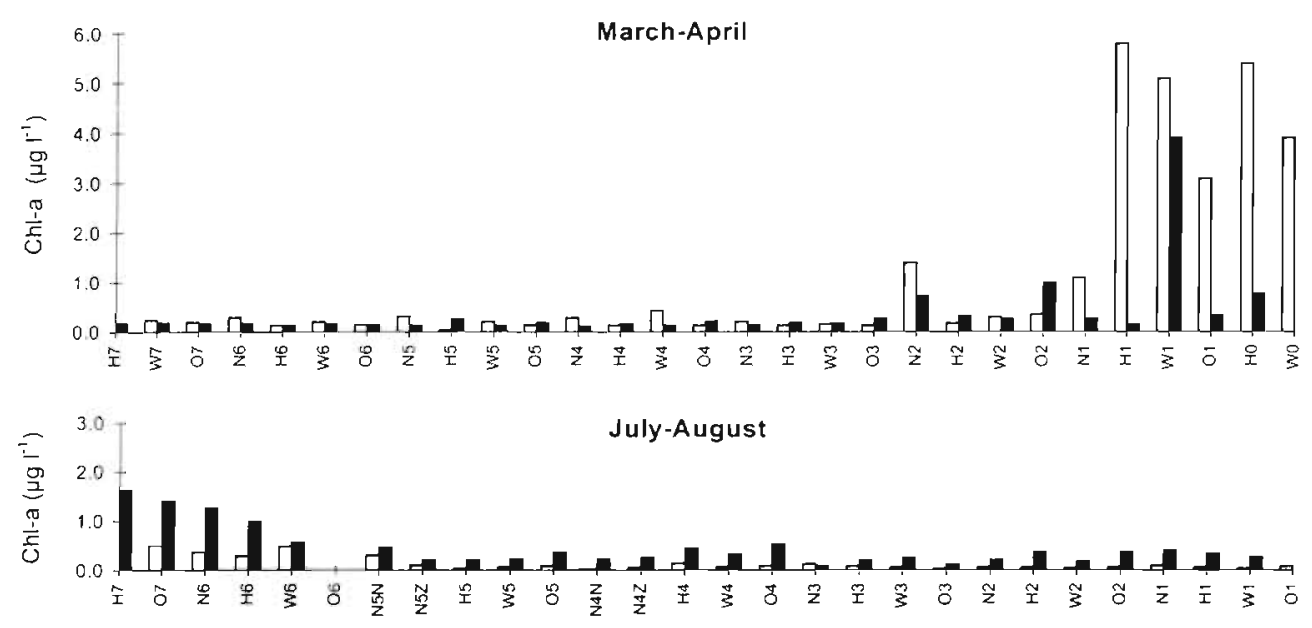

Fig. 5. Chl a concentrations of size fractions $>5 \mu \mathrm{m}$ (open bars) and $<5 \mu \mathrm{m}$ (solid bars) at $10 \mathrm{~m}$ depth along the transect in spring and mid-summer 

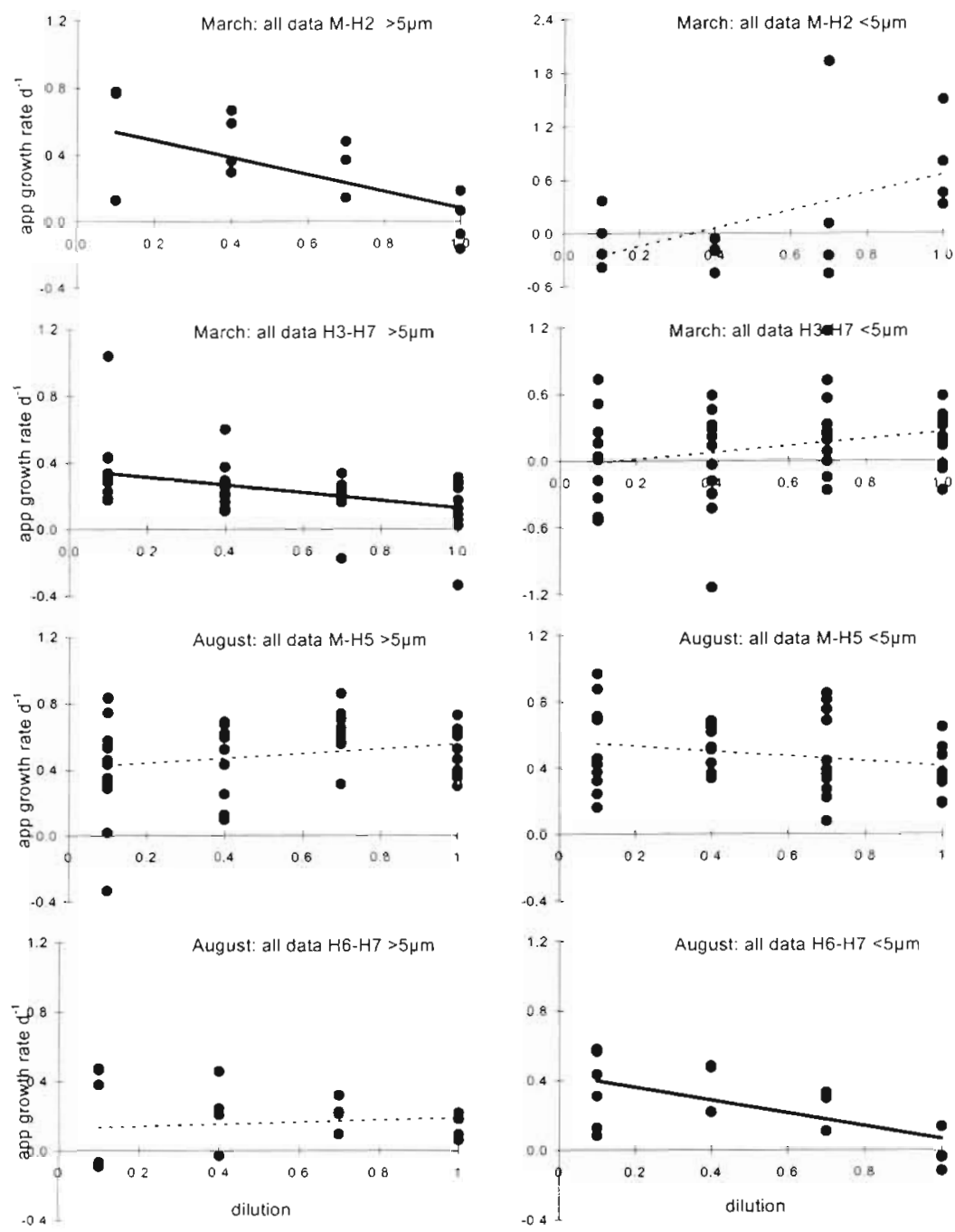

Fig. 6. Linear regressions of apparent daily chl a growth rate, $k_{i}$, versus dilution for different areas and times of year (regression parameters and grazing estimates are shown in Table 2) significant results for the algae $<5 \mu \mathrm{m}$. This was possibly due to a shortcoming in our method, where chl a concentrations at $t_{0}$ were not measured (for which we would have had to prepare twice the amount of dilution bottles) but instead calculated from the $100 \%$ concentrations. The grazing results were possibly biased by the effect of dilution on the accuracy of the chi a measurement this way, especially for the $<5 \mu \mathrm{m}$ fraction.

\section{Grazing in the bloom area in March-April}

At stations where the water column depth was restricted, in the vicinity of Dogger Bank ( $\mathrm{M}-\mathrm{H} 2)$, the increase in solar irradiance in March-April resulted in an algal spring bloom preceding the establishment of temperature stratification. As predicted by the model (see 'Introduction'), the biomass was dominated by large algae. The observation of depletion of nutrients (Riegman et al. 1998) and the low growth rates in the algae $>5 \mu \mathrm{m}$ suggested that the exponential growth phase had ended already. Growth rates for the algae $>5 \mu \mathrm{m}$ were $0.1 \mathrm{~d}^{-1}$ at the Dogger Bank slope stations $(\mathrm{H} 2-\mathrm{H} 1)$ but $0.4 \mathrm{~d}^{-1}$ on top of the bank (HO). The growth rate for the $<5 \mu \mathrm{m}$ fraction was ca $0.3 \mathrm{~d}^{-1}$ (Riegman et al. 1998). When Stns M-H2 were pooled, the micro-
March-April were $0.17 \mathrm{~d}^{-1}$ for the $>5 \mu \mathrm{m}$ fraction and $0.27 \mathrm{~d}^{-1}$ for the $<5 \mu \mathrm{m}$ fraction, measured on the basis of nitrogen uptake (Riegman et al. 1998). Our estimates of grazing for the same area were $g=0.23 \mathrm{~d}^{-1}$ by chl a measurement for algae $>5 \mu \mathrm{m}$ (Table 2) and $g=$ $0.31 \mathrm{~d}^{-1}$ for the nanoplankton as measured by flow cytometry (Table 4), which closely match the above growth estimates and support the idea that microzooplankton grazing was controlling the biomass of the small phytoplankton. Only the significant grazing estimates were used in this comparison; flow cytometry gave nonsignificant results for the algae $>5 \mu \mathrm{m}$ due to the very low numbers, whereas the chl a measurements gave non-
Table 2. Regression parameters and estimated chl a grazing rates $\left(g, \mathrm{~d}^{-1}\right)$ for small and large phytoplankton in 2 areas in spring and mid-summer after pooling the dilution results

\begin{tabular}{|lcrrrrr|}
\hline Time and area & Size & Slope & $\mathrm{r}^{2}$ & $\mathrm{n}$ & $\mathrm{p}$ & \multicolumn{1}{c|}{$g$} \\
\hline March, Stns M-H2 & $<5 \mu \mathrm{m}$ & 1.02 & 0.26 & 16 & 0.04 & -1.02 \\
(spring bloom) & $>5 \mu \mathrm{m}$ & -0.51 & 0.38 & 15 & 0.01 & 0.51 \\
March, Stns H3-H7 & $<5 \mu \mathrm{m}$ & 0.30 & 0.06 & 46 & 0.09 & -0.30 \\
(winter conditions) & $>5 \mu \mathrm{m}$ & -0.23 & 0.17 & 46 & 0.00 & 0.23 \\
August, Stns M-H5 & $<5 \mu \mathrm{m}$ & -0.15 & 0.07 & 46 & 0.09 & 0.15 \\
(oligotrophic conditions) & $>5 \mu \mathrm{m}$ & 0.09 & 0.02 & 46 & 0.32 & -0.09 \\
August, Stns H6-H7 & $<5 \mu \mathrm{m}$ & -0.37 & 0.39 & 18 & 0.01 & 0.37 \\
(Shetland region) & $>5 \mu \mathrm{m}$ & -0.09 & 0.03 & 17 & 0.48 & 0.09 \\
& & & & & & \\
\hline
\end{tabular}


Table 3. (a) Estimates of daily grazing rates, $g\left(\mathrm{~d}^{-1}\right), 95 \%$ confidence interval (CI) and regression coefficient $\left(\mathrm{r}^{2}\right)$ by flow cytometry for algae $<5$ and $>5 \mu \mathrm{m}$ at all of the main stations in March-April. (b) Estimates of daily grazing rates, $g\left(d^{-1}\right)$ by flow cytometry for the different (distinguished and enumerated by flow cytometry) algal size classes ( 2 replicate series [ $a$ and $b$ ] per station) in July-August (significance: . $p<0.05 ; \cdots p<0.01)$

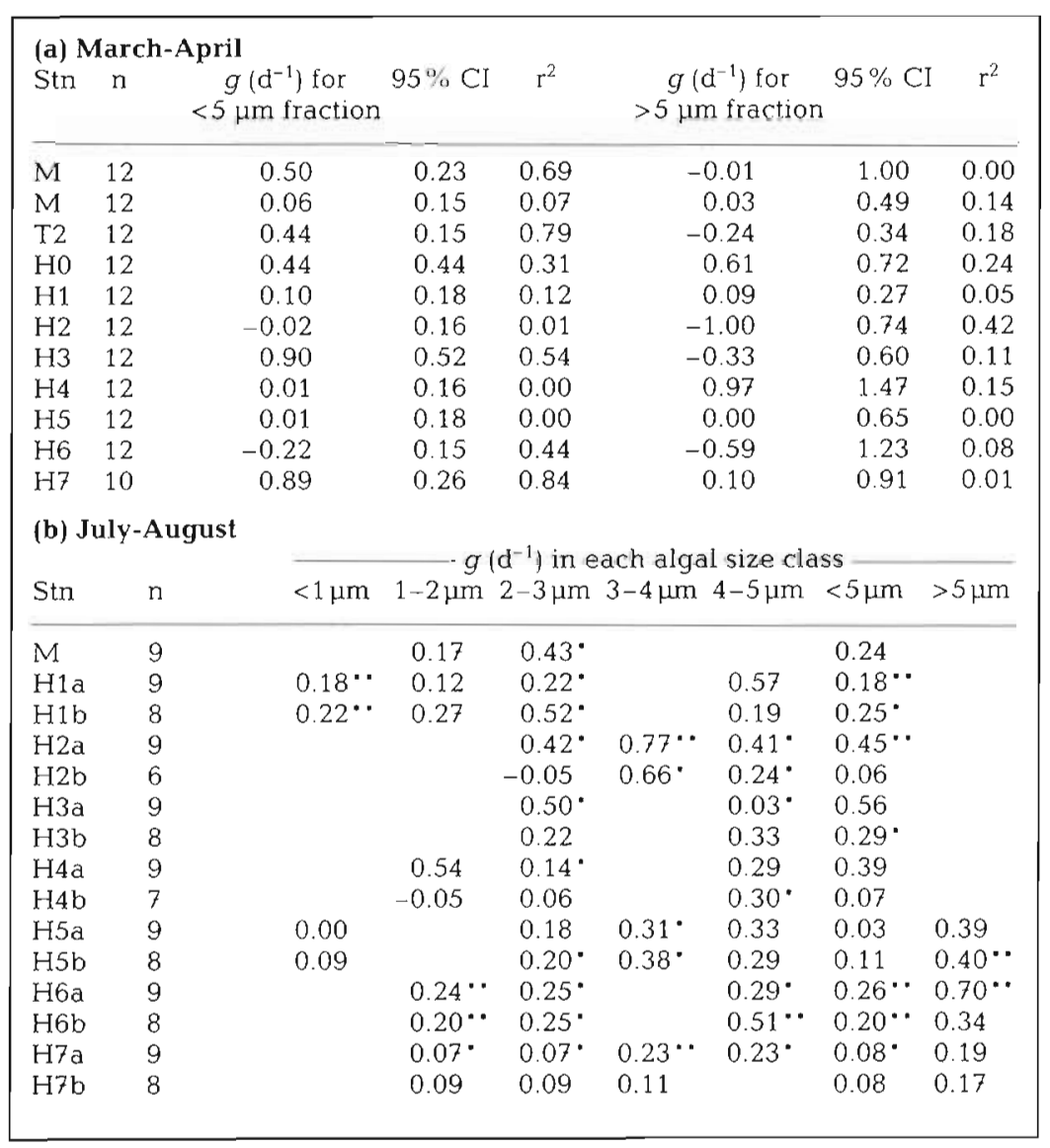

\section{Grazing within the mixed layer in summer}

In the mixed layer of the stratified North Sea, the nutrient uptake during the phytoplankton spring bloom and the first part of the summer ends when the nutrient concentrations above the thermocline have reached the threshold levels for uptake by the smallest phytoplankton and bacteria. We may assume, therefore, that in July-August the algal growth rates in the nutrientdepleted surface layer depended mainly on the additional nutrients produced by the recycling processes in the water. At $10 \mathrm{~m}$, the depth where grazing was measured, carbon growth rates were on average $0.39 \mathrm{~d}^{-1}$ for the $<5 \mu \mathrm{m}$ fraction and $0.43 \mathrm{~d}^{-1}$ for the $>5 \mu \mathrm{m}$ fraction (Riegman \& Noordeloos 1998). Grazing rates determined by flow cytometry were, however, only 0.25 and $0.19 \mathrm{~d}^{-1}$ for the $<5$ and $>5 \mu \mathrm{m}$ fractions respectively (Table 4 ). The remaining average net growth rate of ca $0.2 \mathrm{~d}^{-1}$ for the algae $>5 \mu \mathrm{m}$ seems high for nutrient-depleted conditions, although the numbers of larger algae were very low and only slight sedimentation would compensate for this net production. On the other hand, grazing on the larger algae may have been underestimated since there was a considerable scatter zooplankton grazing rate on the fraction $>5 \mu \mathrm{m}$ was $0.51 \mathrm{~d}^{-1}$ (Fig. 6). Individual stations (Table 1) yielded a wide range of grazing rates, from $-0.65 \mathrm{~d}^{-1}$ at Stn $M$ to $0.89 \mathrm{~d}^{-1}$ at Stn $\mathrm{H} 2$, but only 2 out of 6 of these rates were significant. At $\mathrm{HO}$, where algae $>5 \mu \mathrm{m}$ were still growing rapidly, the estimated grazing rate on this fraction in spring was only $0.11 \mathrm{~d}^{-1}$ (not significant). Grazing rates on the $<5 \mu \mathrm{m}$ fraction were estimated with higher significance by flow cytometry and amounted to $0.25 \mathrm{~d}^{-1}$ for the bloom area (Table 4), which matches the estimated growth rate $\left(0.3 \mathrm{~d}^{-1}\right.$, Riegman et al. 1998) for this fraction. Our data seem to support the hypothesis that small phytoplankton remain under grazing control whereas larger algae can respond with a biomass increase when light availability increases in spring. in the flow cytometer measurements (Fig. 9, bottom left plot) due to the low numbers of cells $>5 \mu \mathrm{m}$ in the $0.5 \mathrm{ml}$ scanned per sample. Grazing estimates for the

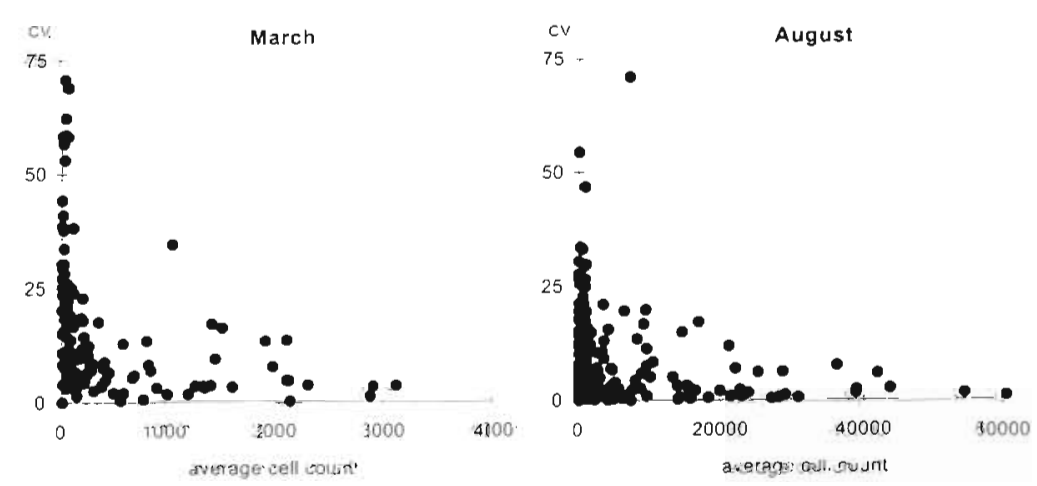

Fig. 7. Coefficients of variation, CV (SD/average $\times 100 \%$ ), of flow cytometer counts for clusters of cells at $t_{24}$ in duplicate incubations versus average cell counts for spring and mid-summer 

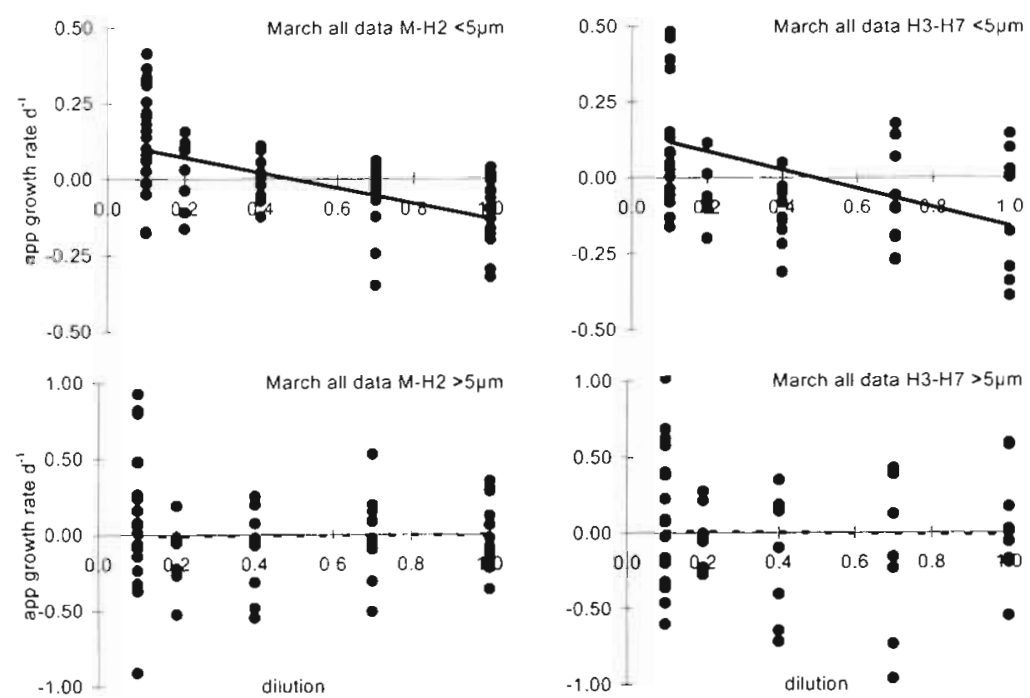

Fig. 8. Apparent daily growth rate $k_{1}\left[=\ln \left(n_{24} / n_{0}\right)\right]$ versus dilution for algae $<5$ and $>5 \mu \mathrm{m}$ counted by flow cytometry in the $\mathrm{M}-\mathrm{H} 2$ and $\mathrm{H} 3-\mathrm{H} 7$ areas in March 1994 with linear regression (dashed lines nonsignificant) (parameters shown in Table 3a)

5 algal size classes $<5 \mu \mathrm{m}$ varied between $g_{1-2 \mu \mathrm{m}}=$ $0.07 \mathrm{~d}^{-1}$ and $g_{3-4 \mu \mathrm{m}}=0.74 \mathrm{~d}^{-1}$; the grazing rate for the $<5 \mu \mathrm{m}$ algal fraction as a whole was $0.25 \mathrm{~d}^{-1}$ (Table 4). Compared with the mentioned average carbon growth rate of $0.39 \mathrm{~d}^{-1}$ for the $<5 \mu \mathrm{m}$ phytoplankton community, the grazing estimates for the 3 algal size classes under $3 \mu \mathrm{m}$ were very low, whereas the algae between 3 and $4 \mu \mathrm{m}$ were grazed much faster than they grew. Different explanations are possible for the discrepancy between these results and the view that growth and grazing rates in the oligotrophic recycling system should be on the same order. Because the algal growth rates were considerably lower than 1 division $\mathrm{d}^{-1}$, it is not likely that a severe overestimation of carbon fixation was the reason. Since a continuous biomass increase of non-settling pico- and small nanophytoplankton in the large research area in the course of the summer cannot have occurred because chl a concentrations were very low, it must be the grazing on algae $<3 \mu \mathrm{m}$ that was probably underestimated. One of the problems we had with the Landry \& Hassett dilution method is that in the oligotrophic area M-H5 the apparent growth rate of the smallest algae, with the lowest biomass (see Fig. 10), increased with increasing dilution only from 100 to
$40 \%$ (natural water), but did not change below $40 \%$. In our opinion the reduction of the prey density to $40 \%$ of the natural levels may have reduced the grazing activity to such an extent that the observed net growth rate already represented ungrazed growth. Further dilution, from 40 to $10 \%$, may therefore have had no effect, with the result that Landry \& Hassett plots including all dilutions given in Fig. 9 underestimate the grazing rates for the smallest 3 algal sizes.

\section{The Shetland region}

Summer chl a concentrations (Fig. 5) were between 0.0 and $0.5 \mu \mathrm{g} \mathrm{l}^{-1}$ from Dogger Bank north to Stn H5 and increased in the vicinity of the Shetlands (H6-H7) to $1.6 \mu \mathrm{g} \mathrm{l}^{-1}$. In contrast to the expected dominance of large algae due to the local input of nutrients in this region (see 'Introduction'), nanophytoplankton appeared to dominate at Stns H6 and H7 (Fig. 10). Carbon growth rates were $0.7 \mathrm{~d}^{-1}$ for the $>5 \mu \mathrm{m}$ fraction and 0.3 to $0.5 \mathrm{~d}^{-1}$ for the $<5 \mu \mathrm{m}$ fraction in area N5Z-H7 (Riegman \& Noordeloos 1998). Grazing estimates (Table 4 ) based on cell counts were $0.35 \mathrm{~d}^{-1}$ for the $>5 \mu \mathrm{m}$ algae and there was considerable scatter in the individual $k_{1}$ estimates.

Table 4. Regression parameters and grazing rate, $g\left(\mathrm{~d}^{-1}\right)$ (determined by flow cytometry), for the different algal size classes in 2 areas in spring and midsummer after pooling the dilution results

\begin{tabular}{|c|c|c|c|c|c|c|c|}
\hline Time and area & $\begin{array}{l}\text { Size } \\
(\mu \mathrm{m})\end{array}$ & $\begin{array}{l}\text { Slope } \\
\left(d^{-1}\right)\end{array}$ & $\begin{array}{l}\mathrm{SD} \\
\left(\mathrm{d}^{-1}\right)\end{array}$ & $r^{2}$ & $\mathrm{n}$ & $\mathrm{p}$ & $\underset{\left(d^{-1}\right)}{g}$ \\
\hline $\begin{array}{l}\text { March-April, Stns M-H2 } \\
\text { (spring bloom) }\end{array}$ & $\begin{array}{l}<5 \\
>5\end{array}$ & $\begin{array}{l}-0.25 \\
-0.01\end{array}$ & $\begin{array}{l}0.05 \\
0.13\end{array}$ & $\begin{array}{l}0.26 \\
0.00\end{array}$ & $\begin{array}{l}69 \\
69\end{array}$ & $\begin{array}{l}0.00 \\
0.93\end{array}$ & $\begin{array}{l}0.25 \\
0.01\end{array}$ \\
\hline $\begin{array}{l}\text { March-April, Stns H3-H7 } \\
\text { (winter conditions) }\end{array}$ & $\begin{array}{l}<5 \\
>5\end{array}$ & $\begin{array}{l}-0.31 \\
-0.03\end{array}$ & $\begin{array}{l}0.09 \\
0.23\end{array}$ & $\begin{array}{l}0.17 \\
0.00\end{array}$ & $\begin{array}{l}58 \\
58\end{array}$ & $\begin{array}{l}0.00 \\
0.91\end{array}$ & $\begin{array}{l}0.31 \\
0.03\end{array}$ \\
\hline $\begin{array}{l}\text { July-August, Stns M-H5 } \\
\text { (oligotrophic conditions) }\end{array}$ & $\begin{array}{c}<1 \\
1-2 \\
2-3 \\
3-4 \\
4-5 \\
<5 \\
>5\end{array}$ & $\begin{array}{l}-0.12 \\
-0.07 \\
-0.20 \\
-0.74 \\
-0.35 \\
-0.25 \\
-0.19\end{array}$ & $\begin{array}{l}0.03 \\
0.04 \\
0.03 \\
0.13 \\
0.04 \\
0.03 \\
0.11\end{array}$ & $\begin{array}{l}0.33 \\
0.05 \\
0.22 \\
0.40 \\
0.42 \\
0.29 \\
0.11\end{array}$ & $\begin{array}{r}34 \\
75 \\
134 \\
49 \\
100 \\
134 \\
26\end{array}$ & $\begin{array}{l}0.00 \\
0.06 \\
0.00 \\
0.00 \\
0.00 \\
0.00 \\
0.10\end{array}$ & $\begin{array}{l}0.12 \\
0.07 \\
0.20 \\
0.74 \\
0.35 \\
0.25 \\
0.19\end{array}$ \\
\hline $\begin{array}{l}\text { July-August, Stns } \mathrm{H} 6-\mathrm{H} 7 \\
\text { (Shetland region) }\end{array}$ & $\begin{array}{c}<1 \\
1-2 \\
2-3 \\
3-4 \\
4-5 \\
<5 \\
>5\end{array}$ & $\begin{array}{c}- \\
-0.15 \\
-0.16 \\
- \\
-0.28 \\
-0.23 \\
-0.35\end{array}$ & $\begin{array}{c}- \\
0.03 \\
0.04 \\
- \\
0.05 \\
0.04 \\
0.08\end{array}$ & $\begin{array}{c}- \\
0.45 \\
0.36 \\
- \\
0.51 \\
0.49 \\
0.37\end{array}$ & $\begin{array}{l}- \\
34 \\
34 \\
- \\
34 \\
34 \\
34\end{array}$ & $\begin{array}{c}- \\
0.00 \\
0.00 \\
- \\
0.00 \\
0.00 \\
0.00\end{array}$ & $\begin{array}{c}- \\
0.15 \\
0.16 \\
- \\
0.28 \\
0.23 \\
0.35\end{array}$ \\
\hline
\end{tabular}



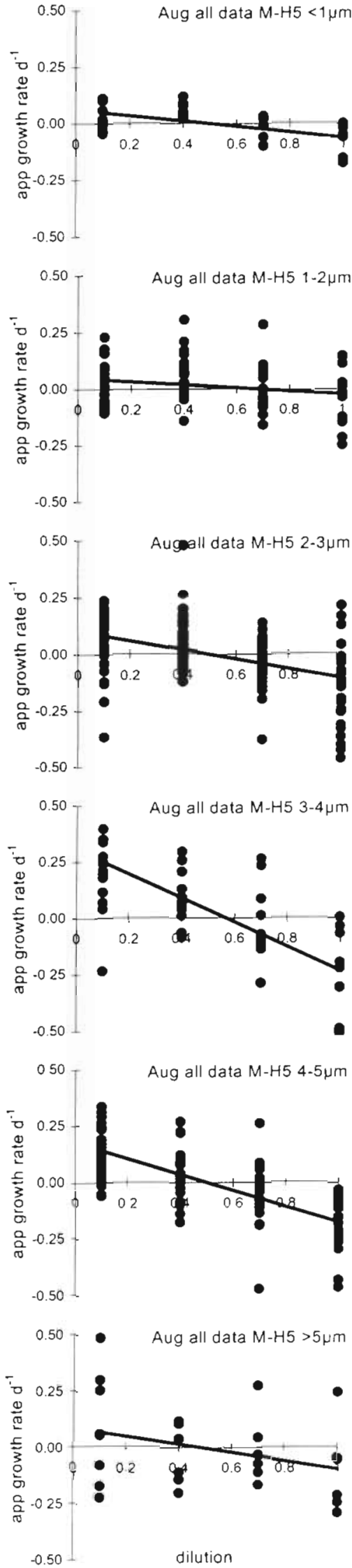
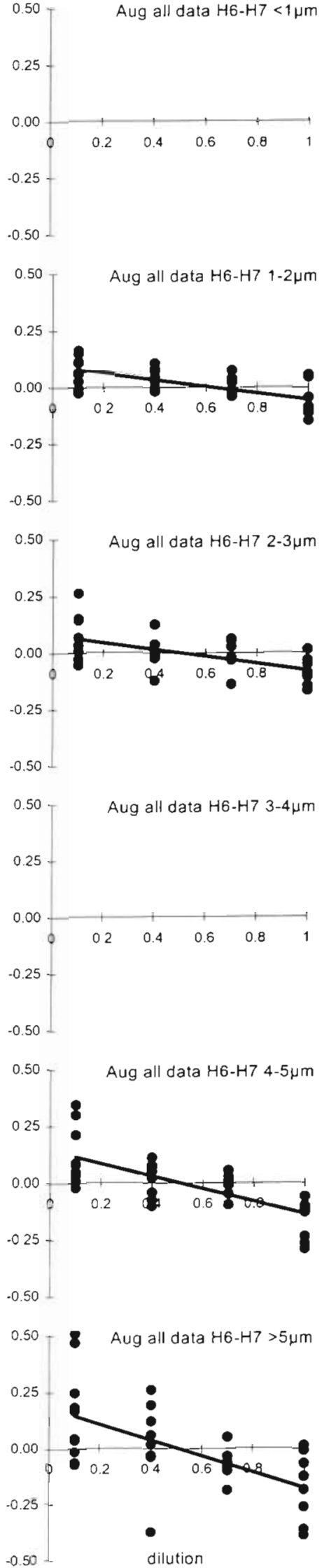

Significant linear fits of $k_{i}$ versus dilution were obtained for the smaller fractions (Fig. 9). Grazing estimates were $0.15,0.16$ and $0.28 \mathrm{~d}^{-1}$ for the $1-2,2-3$ and $4-5 \mu \mathrm{m}$ size fractions, respectively. Pooling Stns $\mathrm{H} 6$ and $\mathrm{H} 7$, overall grazing on nanophytoplankton was $0.26 \mathrm{~d}^{-1}$. As at the more southern stations, grazing rates were low compared with algal growth rates, and, although the estimates were closer for the small fraction, the data do not convincingly demonstrate the expected microzooplankton grazing control of nano- and picophytoplankton near the Shetlands in summer. This conclusion was supported by the high chl a concentrations in the $<5 \mu \mathrm{m}$ fraction. One possible explanation might be that mesozooplankton, which were more abundant at these stations than in the south, may have grazed not only on the larger algae but also on the small herbivores. Another reason for the pico- and nanophytoplankton dominance in the mixed layer near the Shetlands in summer may be the process of mixing with the Atlantic water itself. If we assume that the oceanic microzooplankton are not adapted to North Sea conditions and vice versa, the continuous mixing of shelf and ocean water at Stns $\mathrm{H} 6$ and $\mathrm{H} 7$ may have had a negative effect on microzooplankton grazing

\section{Conclusions}

Landry \& Hassett dilution experiments with samples from the North Sea gave apparent growth rates which were highly variable, especially when algal concentrations were low. When the apparent growth rate values from successive dilution experiments done at different, but comparable, stations were taken together, the significance of the grazing estimates increased considerably. These average estimates for microzooplankton

Fig. 9. Apparent daily growth rate $k$ versus dilution for all different sized clusters in the M-H5 and H6-H7 areas in August 1994 with linear regressions (parameters shown in Table 3b) 
(a)

(b)
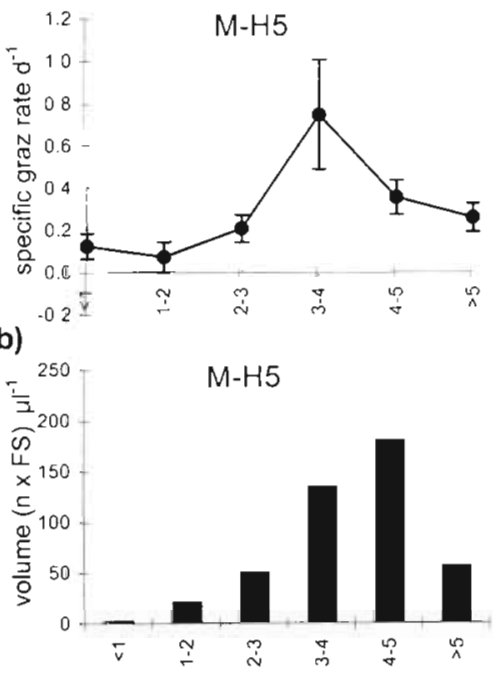

(c)

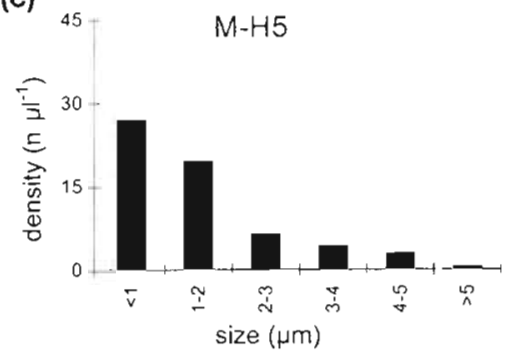

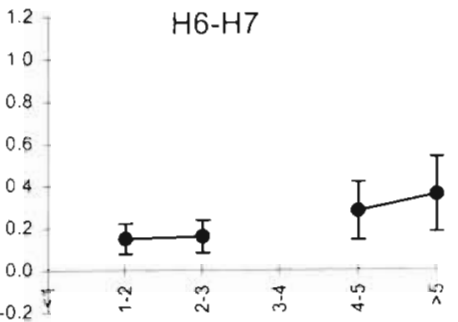
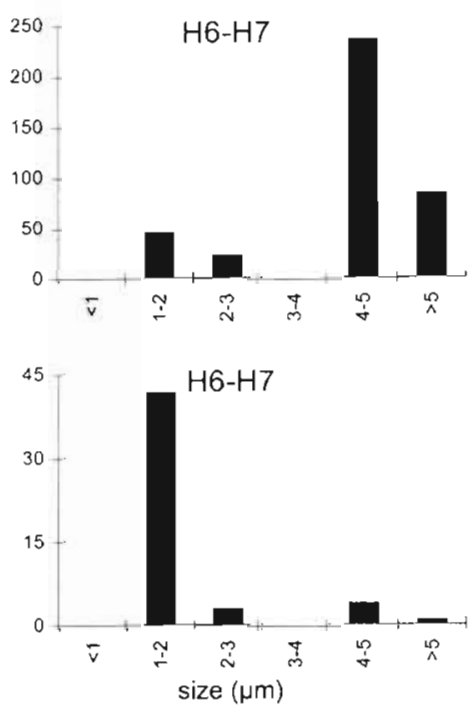

Fig. 10. (a) Estimates of microzooplankton grazing on 6 algal size classes in the $\mathrm{M}-\mathrm{H} 5$ and $\mathrm{H} 6-\mathrm{H} 7$ areas in July-August from Table $3 \mathrm{~b}$ and corresponding food availability according to the flow cytometer counts in the undiluted incubation bottles at $t_{0}$. (b) Relative biovolume of prey (for explanation see text). (c) Prey abundance

grazing for different sea areas agreed better with independent estimates of primary production under light limitation (winter conditions) (Riegman et al. 1998) and under nutrient limitation (mixed layer in the stratified North Sea in summer) (Riegman \& Noordeloos 1998), although grazing was in most cases lower than growth. High concentrations of large algae with rather low growth rates were encountered in early spring in the Dogger Bank area. Grazing rates on these large algae (estimated using chl a concentration) were high, which suggests that the local spring bloom was already in its decline, whereas the grazer populations (especially the larger Strombidium-like ciliates) had increased. In this area growth and grazing in small phytoplankton matched rather well, and according to size fractionated $\mathrm{chl}$ a measurements there had not been a spring bloom in the nanophytoplankton. High concentrations of phytoplankton were also encountered in the nutrientenriched Shetland area in summer, but here small phytoplankton dominated, although both large and small algae showed higher growth rates than loss rates due to microzooplankton grazing. It is possible that predation by mesozooplankton, which were abundant in the Shetland region, caused this local change in the food web structure

Acknowledgements. We wish to thank Captains Souwer of RV 'Pelagia' and Dijkstra of RV 'Zirfaea', the crews and the NIOZ technicians for their great help at sea and Gerhard Herndl, Roel Riegman, Jan Vosjan for their critical reading of the manuscript and the anonymous referees for greatly improving the text. Financial support for this research was provided by the Netherlands Geoscience Foundation of NOW (INP project no. 25.194.02).

\section{LITERATURE CITED}

Banse K (1982) Cell volumes, maximal growth rates of unicellular algae and ciliates, and the role of ciliates in the marine pelagial. Limnol Oceanogr 27:1059-1071

Bird DF, Kalff J (1993) Protozoan grazing and the size-activity structure of limnetic bacterial communities. Can J Fish Aquat Sci 50: $370-380$

Bockstahler KR, Coats DW (1993) Grazing of the mixotrophic dinoflagellate Gymnodinium sanguineum on ciliate populations of Chesapeake Bay. Mar Biol 116:477-487

Burkill PH, Mantoura RFC, Llewellyn CA, Owens NJP (1987) Microzooplankton grazing and selectivity of phytoplankton in coastal waters. Mar Biol 93:581-590

Buskey EJ (1993) Annual pattern of micro- and mesozooplankton abundance and biomass in a subtropical estuary. J Plankton Res 15: 907-924

Capriulo GM, Degnan C (1991) Effect of food concentration on digestion and vacuole passage time in heterotrichous marine ciliate Fibrea salina. Mar Biol 110:199-202

Epstein SS, Shiharis MP (1992) Size-selective grazing of coastal bacterioplankton by natural assemblages of pigmented flagellates, colourless flagellates, and ciliates. Microb Ecol 23:211-225

Evans GT, Paranjape MA (1992) Precision estimates of phytoplankton growth and microzooplankton grazing when the functional response of grazers may be nonlinear. Mar Ecol Prog Ser 80:285-290

Fransz HG, Gonzalez SR, Steeneken SF (1998) Metazoan zooplankton and the structure of the plankton community in the stratified North Sea. Mar Ecol Prog Ser 175:191-200

Frost BW (1991) The role of grazing in nutrient-rich areas of the open sea. Limnol Oceanogr 36:1616-1630

Gerritsen J, Sanders RW, Bradley SW, Porter KG (1987) Individual feeding variability of protozoan and crustacean zooplankton analyzed with flow cytometry, Limnol Oceanogr 32:691-699

Gifford DJ (1988) Impact of grazing by microzooplankton in the Northwest Arm of Halifax Harbour, Nova Scotia. Mar Ecol Prog Ser 47:249-258

Gonzalez JM, Iriberri J, Egea L, Barcina I (1990) Differential rates of digestion of bacteria by freshwater and marine phagotrophic protozoa. Appl Environ Microbiol 56: $1851-1857$ 
Kamiyama T (1992) The impact of grazing by microzooplankton in northern Hiroshima Bay, the Seto Inland Sea, Japan. Mar Biol 119:77-88

Kumar SK, Vincent WF, Austin PC, Wake GC (1991) Picoplankton and marine food chain dynamics in a variable mixed-layer: a reaction-diffusion model. Ecol Model 57:193-219

Kuosa H (1990) Protozoan grazing on pico- and nanophytoplankton in the northern Baltic Sea: direct evidence from epifluorescence microscopy. Arch Hydrobiol 119:257-265

Kuuppo-Leinikki P (1990) Protozoan grazing on planktonic bacteria and its impact on bacterial population. Mar Ecol Prog Ser 63:227-238

Landry MR (1994) Methods and controls for measuring the grazing impact of planktonic protists. Mar Microb Food Webs 8:37-57

Landry MR, Hassett RP (1982) Estimating the grazing impact of marine micro-zooplankton. Mar Biol 67:283-288

Landry MR, Constantinou J, Kirsthein J (1992) Microzooplankton grazing in the Central Equatorial Pacific during February and August 1992. Deep-Sea Res 42:657-671

Landry MR, Kirsthein J, Constantinou J (1995) A refined dilution technique for measuring the community grazing impact of microzooplankton, with experimental tests in the Central Equatorial Pacific. Mar Ecol Prog Ser 120: $53-63$

McManus GB, Ederington-Cantrell MC (1992) Phytoplankton pigments and growth rates, and microzooplankton grazing in a large temperate estuary. Mar Ecol Prog Ser 87: $77-85$

Moisan T, Putt M, Stoecker D (1991) Bacterivory in McMurdo Sound: 2. Information from size fractionation experiments. Antarct J US 26:141-142

Neuer S, Cowles TJ (1994) Protist herbivory in the Oregon upwelling system. Mar Ecol Prog Ser 113:147-162

Ohman MD, Snyder RA (1991) Growth kinetics of the omnivorous oligotrich ciliate Strombidium $\mathrm{sp}$. Limnol Oceanogr 36:922-935

Paranjape MA (1990) Microzooplankton herbivory on the Grand Bank (Newfoundland, Canada): a seasonal study. Mar Biol 107:321-328

Putt MDK, Stoecker D (1989) An experimentally determined carbon:volume ratio for marine 'oligotrichous' ciliates from. estuarine and coastal waters. Limnol Oceanogr 34: $1097-1103$

Editorial responsibility: Otto Kinne (Editor),

Oldendorf/Luhe, Germany
Rassoulzadegan F, Sheldon RW (1986) Predator-prey interactions of nanozooplankton and bacteria in an oligotrophic marine environment. Limnol Oceanogr 31: $1010-1021$

Riegman R, Kuipers BR (1994) Resource competition and selective grazing of plankton in a multispecies pelagic food web model. PSZN I: Mar Ecol 15:153-164

Riegman R, Noordeloos AAM (1998) Size fractionated uptake of nitrogenous nutrients and carbon by phytoplankton in the North Sea during summer 1994. Mar Ecol Prog Ser 175:95-106

Riegman R, Kuipers BR, Noordeloos AAM, Witte HJ (1993) Size-differential control of phytoplankton and the structure of plankton communities. Neth J Sea Res $31: 255-265$

Riegman R, Flameling IA, Noordeloos AAM (1998) Size-fractionated uptake of ammonium, nitrate and urea and phytoplankton growth in the North Sea during spring 1994. Mar Ecol Prog Ser 175:85-94

Sherr BF, Sherr EB, Fallon RD (1987) Use of monodispersed, fluorescently labeled bacteria to estimate in situ protozoan bacterivory. Appl Environ Microbiol 53:958-965

Sherr BF, Sherr EB, Pedros-Alio C (1989) Simultaneous measurement of bacterioplankton production and protozoan bacterivory in estuarine water. Mar Ecol Prog Ser 54: 209-219

Strickland JDH, Parsons TR (1972) A practical handbook of seawater analysis. Bull Fish Res Board Can 167:1-311

Strom SL, Welschmeyer NA (1991) Pigment-specific rates of phytoplankton growth and microzooplankton grazing in the open subarctic Pacific Ocean. Limnol Oceanogr 36 $50-63$

Verity PG (1985) Grazing, respiration, excretion and growthrates of tintinnids. Limnol Oceanogr 30:1268-1282

Verity PG (1986) Grazing of phototrophic nanoplankton by microzooplankton in Narragansett Bay. Mar Ecol Prog Ser 29:105-115

Verity PG, Stoecker DK, Sieracki ME, Nelson JR (1993) Grazing, growth and mortality of microzooplankton during the 1989 North Atlantic spring bloom at $47^{\circ} \mathrm{N}, 18^{\circ} \mathrm{W}$. DeepSea Res 40:1793-1814

Xiuren N, Vaulot D (1992) Estimating Synechococcus spp. growth rates and grazing pressure by heterotrophic nanoplankton in the English Channel and the Celtic Sea. Acta Oceanol Sin 11:255-273

Submitted: February 23, 1998; Accepted: October 19, 1998 Proofs received from author(s): April 7, 1999 